\title{
SUSTAINING PEACE AND STABILITY IN GHANA \\ Appraising the Role of the National Election Security Task Force in the 2012 Elections
}

\section{Festus Aubyn and Mustapha Abdallah}

Festus Kofi Aubyn is a researcher in the Faculty of Academic Affairs and Research of the Kofi Annan International Peacekeeping Training Centre,

Ghana, and a doctoral candidate in Peace and Conflict Studies at the

University of Ibadan, Nigeria

e-mail: festus.aubyn@kaiptc.org

Mustapha Abdallah is a research associate in the Faculty of Academic

Affairs and Research of the Kofi Annan International Peacekeeping

Training Centre, Ghana.

e-mail: mustaphah.abdallah@kaiptc.org

\begin{abstract}
This article examines the role of the National Election Security Task Force (NESTF) in the 2012 elections in Ghana. It traces the history of electoral politics in Ghana's Fourth Republic, highlighting significant developments and security challenges from 1992, with a particular focus on the 2012 elections. The structure, composition and powers as well as the functions of the NESTF are discussed. The article further examines the performance of the NESTF during all three phases of the elections relative to security challenges, responses and emerging issues that require urgent policy reforms. Based on face-to-face interviews and participant observations, the article concludes that the 2012 elections were not only keenly contested but all three phases were marred by extreme violence, particularly because of the novelty of the biometric voter registration and verification system. While commending various election stakeholders such as the Electoral Commission of Ghana, we argue that although the election results were contested in court, the NESTF, in particular, played an exemplary role in averting possible conflict after the declaration of the results. We recommend, however, that in subsequent elections the security forces should be seen to be neutral and government should also ensure adequate provision of logistics, transport and communication devices to ensure free, fair and violence-free elections.
\end{abstract}




\section{INTRODUCTION}

None of the elections during Ghana's Fourth Republic has witnessed more campaigns for peace than those held on 7 December 2012. The reason for this is that although Ghana has an enviable record of conducting credible and peaceful elections the 2012 elections presented a major challenge in respect of whether the country would maintain this tradition and hold another peaceful and transparent election, whose outcome would be acceptable by all, particularly the two main political parties, the National Democratic Congress (NDC) and the New Patriotic Party (NPP). The reason for this concern was several security threats that characterised the political landscape in the country prior to the 2012 poll.

The 2012 poll marked the introduction by the Electoral Commission of Ghana (ECG) of the biometric voter register (BVR) and verification system (VS) (CODEO 2012) and the tensions and election-related violence that characterised the BVR exercise raised fears about its successful implementation.

Another potential threat was the alleged 'secret tapes', which appeared to reveal plans by people high up in the NPP and NDC to destabilise the electoral process (Zamana 2012; African Elections 2012). This issue became a serious security concern and the subject of intense public debate. A third problem was the acrimonious debates over the creation by the ECG of 45 additional constituencies a few months before the date of the election (Coffie 2012; CDD 2012).

The blatant use of aggressive, intimidating and violent language in public political discourse in the media and on political platforms as well as the increasing level of media polarisation and biased political reportage was a fourth major concern. Other major problems were the use of youth vigilante groups and private security guards known as 'Macho men' to harass and intimidate political opponents (Alhassan 2012; KAIPTC 2012) and the high level of mistrust among political parties of state institutions such as the ECG, the judiciary and the security agencies suspected to lack objectivity and be political biased.

Lastly, the issue of the availability and proliferation of small arms and light weapons, increasing tension between farmers and pastoralists, growing dissatisfaction among the coastal communities over Ghana's oil find and pressure in some mining communities over the issue of 'Galamsey' (illegal mining), chieftaincy related tensions and communal violence all posed a critical threat to the successful outcome of the 2012 poll (WANEP 2012).

In addition to these internal security challenges were external threats that also sought to undermine the hard-won democratic gains of the country ahead of the election. Notable among these was the influx of Ivorian ex-combatants, mercenaries and rebels into the country and its tendency to increase the availability of arms in the hands of non-state actors (WANEP 2012). All these issues added up to the highly competitive nature of the electoral process. 
Against the backdrop of these worrying trends and security threats, ensuring that the election was peaceful remained a veritable challenge. Though the ECG is constitutionally mandated to conduct and supervise all national-level elections, the success and credibility of the process is the shared responsibility of all the stakeholders - political parties, security agencies, government, citizens, election observers, civil society groups and media. But of all these stakeholders it was the maintenance by the security agencies of public law and order as well as the safety of persons and properties that was critical to the peaceful outcome of the election.

For this reason, and drawing on the experience of previous elections, the Ghana Police Service (GPS), together with the other allied security agencies, formed the ad hoc National Elections Security Task Force (NESTF) a few months before the 2012 elections, to ensure that peace prevailed before, during and after the elections. The NESTF comprised all the security agencies and existed at national level with divisions at regional, divisional and district levels. Using information gleaned from face-to-face interviews and participant observation we seek in this article to assess critically the NESTF and the way it performed its role in ensuring security. ${ }^{1}$

The article has six parts. In the first we examine Ghana's politics under the Fourth Republic, highlighting the major features, security challenges and transformations from 1992 to 2008. The second section looks at the 2012 elections in perspective, identifying all the critical issues that posed a threat to the peaceful outcome of the elections. The third section discusses the structure and composition of the NESTF, while the powers and mandate of the taskforce are discussed in the fourth section. The fifth examines the preparation of the NESTF for the elections and assesses its performance with respect to its mandate as well as some of the challenges it encountered. Some emerging issues that require urgent reform are also discussed. Lastly, we offer some practical recommendations on how to improve the task force for future elections.

\section{AN OVERVIEW OF ELECTORAL POLITICS IN GHANA'S FOURTH REPUBLIC}

Electoral politics in Ghana's Fourth Republic began with the promulgation and adoption of the 1992 Constitution, which reinstated multiparty democracy under the leadership of Jerry John Rawlings.

1 The interviews were conducted with individuals in the security forces and experts / participants in the Colloquium on Ensuring Peaceful Elections in Ghana, 'Preserving National Security in Elections 2012 and Beyond', organised by the Kofi Annan International Peacekeeping Training Centre, Accra, Ghana, October, 2012. 
Having twice seized power in military coups Rawlings accepted the shift towards multiparty democracy as a result of both domestic and international pressure.

On the domestic front there was a relentless and growing demand from various pressure groups and civil society organisations that the 'culture of silence' be broken and reforms be introduced in governance and political processes (Frempong 2007, p 134). Indeed, in the latter part of the 1980s and early 1990s a significant number of Ghanaians had become conscious of their rights and were no longer prepared to accept suppression and dictatorship as a form of leadership and governance, believing that dictatorship should give way to democracy, where citizens can choose their leaders or representatives through a majority votes.

Concurrently with the increasing pro-democratic culture after the Cold War, which had a contagious effect across Africa, the PNDC government succumbed to pressure and a new Constitution was drafted and approved by means of a referendum in 1992, ushering in the Fourth Republic.

One important feature of the Fourth Republic has been the change of governments through competitive elections under the supervision of the Interim National Electoral Commission (INEC) in 1992 and, subsequently, the Electoral Commission of Ghana. The INEC and the ECG, both described as credible democratic institutions, have organised and supervised six successful presidential and parliamentary elections (1992, 1996, 2000, 2004, 2008 and 2012). Unlike the situation in the previous republics, where regimes were changed through the barrel of the gun, the use of elections and the 'power of the thumb' has remained an important characteristic of Ghana's Fourth Republic.

Apart from this overarching feature electoral politics in the Fourth Republic has also been characterised by the fact that two dominant political parties have alternated power, with each of them serving two terms and simultaneously dominating parliamentary seats. All elections apart from that in 1992 have been presided over by the same electoral commissioner, Kojo Afari Djan. Moreover, the media, civil society organisations, constitutionally mandated institutions such as the National Media Commission (NMC) and Commissioner for Human Rights and Administrative Justice (CHRAJ) and domestic as well as international observers have played an increasingly important role. In particular, the issue of election observation in the 1992 transitional and subsequent elections became important, largely due to external and domestic concern for multiparty democracy and for ensuring free and fair elections (Gyimah-Boadi 1999; Jeffries \& Thomas 1993).

In spite of this transformation, however, there has been a host of irregularities (Gyima-Boadi 2003, pp 131-2; Ayee 1998, p 35) and election-related violence, which, in one way or another, have threatened to undermine the internal peace and stability of the country (Aubyn 2012, p 240). These have arisen from multiple 
factors such as the lack of transparency of the electoral system and processes, perceived and real rigging by party officials, the exploitation of incumbency and the bloating of the electoral register (Ayee 1998). The associated tensions and violence in all three phases of elections remained issues of concern from 1992 to 2008 (Gyimah-Boadi 2003, pp 131-2; Ayee 1998, p 85; Frempong 2012; BoafoArthur 2008, p 38).

In 2008, for the first time, fear and tension gripped the entire nation prior to the declaration of the results, after a third round of voting. Indeed, the future of the nation rested on a knife edge (Frempong 2012, p 136) as the election cycle was highly competitive, without an incumbent and clear frontrunner. Against this background, slogans such as 'mother of all elections', 'win or die', 'there can be no loser', 'we will win at all cost' (Aning \& Lartey 2009), 'Ghana will be like Kenya', began to emerge on the political landscape. These utterances challenged the security forces to be extra alert about possible security infractions by supporters of the two leading parties.

As expected, violence characterised all three phases of the elections. As Danso \& Lartey (2012) note, a registration exercise that should normally be conducted peacefully was characterised by acts of vandalism and attacks on journalists and party agents as well as on civilians, particularly in the Volta, Ashanti and Northern regions.

In the post-election period the security forces struggled to maintain law and order as supporters of the NDC, incited by pro-NDC radio station, besieged the offices of the electoral commission in anticipation of the final results. Similarly, NPP supporters inundated a local radio station to protest against its line of reporting, allegedly slanted towards the NDC (Frempong 2012).

These isolated incidents created an atmosphere of panic and tension and there was a growing fear that the situation could degenerate into conflict. However, the threats of the outbreak of conflict, particularly during the 2008 elections, were averted by the efficient and collaborative role of the security forces, which, unlike during the military era, have become somewhat 'sanitised', operating more as enforcers of the law than as perpetrators of human rights abuses.

\section{THE 2012 ELECTIONS IN PERSPECTIVE}

Like the 2008 elections the 2012 elections were crucial, with the NDC keen to maintain the power it had won in 2008 and the NPP anxious to defeat it. The NDC had won the 1992 and 1996 elections, while the NPP had won those in 2000 and 2004 and the power had shifted back to the NDC in 2008. In essence, only the NDC and NPP have alternated power since the Fourth Republican Constitution in 1992 and Ghana can be described as a two-party state. 
An NDC victory in the 2012 elections would affirm what Huntington terms the mechanistic two-turnover test of democratic consolidation (Frempong 2012, p 143) and, more importantly, the NDC would have the opportunity to benefit from the country's newly-discovered oil resources. On other hand, a loss by the opposition NPP would mean that Nana Akufo-Addo, having twice stood as the party's presidential candidate (2008 and 2012) would become unpopular, which would put paid to his vaulting ambition to become president of Ghana and this, arguably, might affect the fortunes of the party in subsequent elections.

The quest by the NDC to maintain power and by the NPP to win it became a matter of concern among the rank and file of the two parties. The frustrations of the NPP in particular were reflected in NPP presidential candidate Akufo-Addo's catch phrase, 'all-die-be-die', ${ }^{2}$ a phrase that was heavily criticised and subjected to varied interpretations by the political class, the religious fraternity and the broad mass of party followers (Danso \& Adu-Afful 2012). The danger of the statement is the inherent ethnic undertones that sought to instigate and encourage the use of violence in the elections. The flag bearer arguably encouraged his followers, who are predominantly from the Akan ethnic group, to muster courage and fight the ruling NDC if its members engaged in any acts of violence or exploited the electoral process to their advantage. Although Akufo-Addo later defended the phrase as harmless, the statement had already gained currency among the youth and consequently raised the political temperature and security concerns in the country.

As the political temperature rose, the incumbent president, John Atta Mills died - an unprecedented occurrence in the political history of Ghana. The death gave a new twist to the political campaign - the NDC now had to 'sell' a new candidate to the electorate. While some NDC followers felt the death of President Mills was a blessing in disguise because he was increasingly losing appeal due to his ill health, others believed the new leader, John Dramani Mahama, faced a daunting task in competing with Akufo-Addo, a well-known lawyer and former minister of foreign affairs.

As a result, the election campaign became more competitive, and also more tense, with the revelations of 'alleged secret tapes' by the two main political parties to derail the electoral process (Zamana 2012). On the one hand, the NDC alleged that NPP National Youth Organiser Anthony Karbo was planning to disrupt the December 2012 polls by engaging the services of mercenaries, described as 'bad

2 The interpretation of 'all-die-be-die' is that party followers should demonstrate commitment even if it means dying for the NPP in the face of provocation. Party followers should not allow themselves to be cowed into submission nor be intimidated by the ruling NDC, at whose hands the NPP suffered attacks in previous elections. Another interpretation is that Akufo-Addo was inciting the predominantly Akan ethnic group in the NPP to resort to violence against minority tribes that dominate the ruling NDC. 
boys', from Togo, Liberia, Nigeria and Libya (Ghanaweb 2012 ). On the other, the NPP released a secret tape in which it alleged that the NDC had hatched a plan to recruit a special force whose members would be given national security identification cards to enable them move freely as security operatives and cause trouble in some parts of the country during the elections (Peace FM Online 2012).

But what evoked enormous controversy and generated heated debate among the two main political parties, the religious fraternity and the broad mass of civil society organisations was a secret tape believed to have been released by the NDC and linked to a series of sermons delivered by Pastor Mensah Otabil, General Overseer of the International Central Gospel Church (ICGC), who is widely believed to be a member of the NPP and who has a significant following in the country.

The so-called secret tape contained statements that suggested that Otabil sought to undermine the party's main campaign message - the provision of free senior high school education, a message that differed from that of the NDC, which focused on improving the quality of education. While the NPP's policy on free education gained increasing traction among the broad masses of the youth, the NDC allegedly and logically pieced together different sermons delivered by the pastor suggesting that free education was impossible in the circumstances prevailing in the country at the time.

The repeated playing of the message on the airwaves went down well with the majority of Ghanaians and was intended to create disaffection between the renowned pastor as an individual and the NPP on the one hand and the wider Christian community on the other. We argue that although the secret tape created tensions it could also be described as a dirty but politically grand scheme by the NDC to recapture the attention of the youth and persuade them to buy into the party's policy of providing quality rather than free education.

Another critical concern was the introduction of the biometric voter register and verification system (CODEO 2012). The concern stemmed from the fact that during the registration phase security forces had faced the daunting task of maintaining peace and security at various polling centres when the machines broke down, raising fears that similar difficulties might be encountered on election day. For this reason and in consonance with the avowed commitment of the government and the ECG to ensure free, fair, transparent and credible elections, the NESTF was established.

\section{THE NATIONAL ELECTIONS SECURITY TASK FORCE: STRUCTURE AND COMPOSITION}

The NESTF, the election security framework for elections in Ghana, is an ad hoc security arrangement which is usually inaugurated by the inspector-general of 
police (IGP) a few months prior to national and district-level elections. It consists of all the state security agencies including the Ghana Police Service (GPS), Ghana Armed Forces (GAF), Fire Service, Immigration Service, Customs, Excise and Preventive Service (CEPS), Prison Service, Bureau of National Investigations (BNI) and the External Intelligence Service (GPS, 2008; Aubyn \& Lartey 2012). Other co-opted members include the National Commission for Civic Education (NCCE), the Ghana Information Services, the National Ambulance Service and the National Disaster Management Organisation (NADMO).

The co-opted members are specifically responsible for public education as well as any possible casualties incurred during the elections. The GPS is the lead security agency of the NESTF primarily because it is the only state agency constitutionally mandated to maintain internal security, law and public order (GPS 1970; Constitution of Ghana 1992). All the other allied security agencies are included in the taskforce to support the NESTF due to the human resources constraints of the GPS. The NESTF exists or is decentralised at national, regional, zonal (police divisions) and district level.

At the national level it is called the National Taskforce (NTF) and represents the highest decision-making body of the NESTF. All regional, zonal and district task forces report or are responsible to the NTF. It is headed by the inspectorgeneral of police, who is also the national chairman, with the deputy IGP as the national vice-chairman. Members include selected representatives from the headquarters of all the security agencies, the ECG and the Ministry of Local Government (GPS 2008).

The Joint Regional Security Task Force (JRTF), as it is called at the regional level, is chaired by the regional police commander and co-chaired by his/her deputy (GPS 2008). The JRTF is responsible for the work of the NESTF at the regional level and reports to the national chairman of the NTF. The members are the regional commanders and communication officers of all the security agencies, the regional electoral officers and regional co-ordinating directors.

The Zonal Joint Security Services Task Force at the divisional level, on the other hand, is headed by the divisional police commander and includes the divisional or sector commanders of all the security agencies together with municipal co-ordinating directors and municipal electoral commission officers and is answerable to the JRTF. Lastly, at the district level, there is the Joint District Security Task Force (JDSTF), which is also headed by the district police commander, with its members synonymous with those of the Zonal Joint Security Services Task Force at the divisional level.

In order to facilitate the work of the task force, sub-committees were established at each level (see Table 1) to do the operational work of the NESTF. Membership of the various sub-committees was determined by a person's 
expertise and knowledge in the area. In other words, membership was dictated by 'best fit' to function (involving a division of labour among the security services).

Table 1

NESTF sub-committees and their functions

\begin{tabular}{|c|c|}
\hline Sub-committees & Functions \\
\hline $\begin{array}{l}\text { The Planning, Implementation, Monitoring and } \\
\text { Coordinating Sub-committee }\end{array}$ & $\begin{array}{l}\text { The highest policy body of the NTF } \\
\text { for policy formulation, planning, } \\
\text { implementation, monitoring and } \\
\text { coordinating all the activities of the } \\
\text { various sub-committees }\end{array}$ \\
\hline $\begin{array}{l}\text { The Joint National Operations Room and } \\
\text { Secretariat (located at the police information room } \\
\text { in Accra) }\end{array}$ & $\begin{array}{l}\text { As the national secretariat of the } \\
\text { NESTF it receives and collates } \\
\text { sitreps and other correspondence } \\
\text { and disseminates them to the } \\
\text { competent authorities approved by } \\
\text { the IGP }\end{array}$ \\
\hline Legal and Prosecution Sub-committee & $\begin{array}{l}\text { The correct conduct of police } \\
\text { investigations and prosecutions of } \\
\text { all criminal and electoral offences } \\
\text { before, during and after the } \\
\text { elections }\end{array}$ \\
\hline Election Liaison Officers Sub-committee & $\begin{array}{l}\text { Liaises with the ECG and } \\
\text { its officials, other security } \\
\text { organisations that contribute } \\
\text { personnel and material resources } \\
\text { for the task force and the print and } \\
\text { electronic media to ensure good } \\
\text { communication and information } \\
\text { flows }\end{array}$ \\
\hline Ballot Boxes Security Sub-committee & $\begin{array}{l}\text { Formulates policies or directives } \\
\text { on security of ballot boxes, ballot } \\
\text { papers, election officials, polling } \\
\text { stations, election material or } \\
\text { officials in transit and collation } \\
\text { centre security }\end{array}$ \\
\hline The Investigations Sub-committee & $\begin{array}{l}\text { Informs the IGP of any involvement } \\
\text { of a public officer in electoral } \\
\text { offences or malpractices and } \\
\text { nefarious activities and also } \\
\text { investigates all cases related to } \\
\text { elections }\end{array}$ \\
\hline
\end{tabular}




\begin{tabular}{|l|l|}
\hline The Financial Sub-committee & $\begin{array}{l}\text { Collates budget and logistics } \\
\text { requirements of the task force and } \\
\text { advises national chairman on the } \\
\text { source of funding }\end{array}$ \\
\hline Intelligence Sub-committee & $\begin{array}{l}\text { Intelligence and information } \\
\text { gathering, processing and } \\
\text { dissemination for proactive and } \\
\text { reactive operations }\end{array}$ \\
\hline The Transport Sub-committee & $\begin{array}{l}\text { Deliberates on the mobilisation } \\
\text { and commandeering of vehicles } \\
\text { from the other allied security } \\
\text { agencies, electoral commission, } \\
\text { Ministry of Local Government and } \\
\text { Rural Development, Metropolitan, } \\
\text { Municipal and District assemblies, } \\
\text { private transport union, intercity } / \\
\text { STC and metro mass transit to } \\
\text { convey personnel and transport } \\
\text { electoral materials }\end{array}$ \\
\hline
\end{tabular}

Source: GPS 2008; Aubyn \& Lartey 2012

\section{Powers and functions of the NESTF}

The NESTF was charged primarily with maintaining law and order, protecting life and property and dealing professionally and firmly with any breaches of the peace and the ECG Code of Conduct before, during and after the elections (GPS 2008; Government of Ghana 2012; GraphicOnline 2012).

The execution of this function was divided among three categories of the taskforce, namely, the static force, the mobile force and a standby or contingency force (Aubyn \& Lartey 2012; fieldwork 2013). The work of the three forces was complementary and mutually reinforcing and covered all three phases of the elections. The static force was responsible for manning and protecting the polling stations, the country's borders, electoral offices, voters, ballot boxes, electoral officials, and collation centres (Aubyn \& Lartey 2012; fieldwork 2013).

The force also provided heavy security protection during political party campaigns and meetings and the safe escort of all voting materials to and from polling stations, before, during and after the elections. The mobile force, on the other hand, undertook massive patrols in the electoral areas and, especially, conflict prone areas or flashpoints, to deal with any unforeseen events. Lastly, the standby or contingency force provided support to the other two forces in case of emergencies; thus, it only consisted of specialised police units like the Police 
Rapid Deployment Force, the Armoured Car Squadron, the Mounted Squadron, the Striking Force and military contingents (Aubyn \& Lartey 2012; fieldwork 2013; Myjoyonline 2012a). It reacted promptly to reinforce and contain any crisis situation.

\section{PREPARATION FOR THE 7 DECEMBER ELECTIONS AND BEYOND}

The prime objective of the security agencies from January 2012 to election day and its aftermath was to maintain peace and security. In addition, all of them, especially the police, were expected to continue with their traditional roles in maintaining peace and public order as well as fighting crime. Thus the police and the military continued with the operation dubbed Camp Drive, a police-military patrol that fought the menace of armed robbery day and night throughout the electoral period to prevent criminals from taking advantage of their preoccupation with election duties (KAIPTC 2012).

The most important aspect of the NESTF's preparation concerned the need to ensure the necessary logistics, equipment, personnel strength and training, funding, accommodation and personnel welfare and other pertinent issues (Government of Ghana 2012; Myjoyonline 2012a). Other elements of its work included a comprehensive plan to identify all flashpoints in the country where violence was likely to erupt during the elections, in order to double security patrols at such points.

Training programmes and orientation sessions were organised in all regions and districts in the country to build the capacity of all law enforcement agencies. This was done with the support of the United Kingdom government through UK Aid and the Department of International Development (DFID), the Hans Seidel Foundation and the Government of France (KAIPTC 2012; fieldwork 2013). One such training programme undertaken by the military was codenamed Exercise Bridget and involved drills and scenario-building exercises on how to respond to emergency situations (Mishio 2012; KAIPTC 2012). The police were also taken through some formal training sessions on their election duties by a company called Executive Diligence (Ghana News Agency 2012).

Security officers who were deployed for election duty were given printed notes or fliers detailing their prime duties, to guide them in taking decisions when confronted with tricky situations. However, most of the training programmes involved only senior and middle-level police officers and military personnel, to the disadvantage of the other security agencies. This created a situation where most of the security officers, especially from the fire service, immigration and CEPS, lacked essential knowledge about the electoral laws and a clear understanding of what their specific roles or duties were (fieldwork 2013). Perhaps a standardised 
training programme should be developed for all members of the taskforce, to enable them to gain the necessary theoretical and practical knowledge to perform their electoral duties professionally and effectively.

Funding was yet another important component of the taskforce's preparatory processes. In order to execute their expected roles effectively they required vehicles to patrol and to transport officers to and from their areas of operations. They also required communication devices, shockers and batons to control crowds and rations to meet personnel subsistence needs while on election duty.

Although the government provided some financial assistance as part of the electoral budget to cover rations and other logistical needs it was insufficient. The taskforce still lacked much of the necessary equipment (fieldwork 2013). These constraints not only limited the effectiveness and efficiency of their operations, they also affected their timely response to crisis situations.

\section{ASSESSING THE PERFORMANCE OF THE NESTF}

The role of the NESTF covered all phases of the electoral process: pre-election, election day and the post-election period. As indicated above, the taskforce had specific tasks to perform in each phase of the process.

\section{The pre-election period}

During the pre-election period the taskforce ensured the safe escort of all voting materials to and from the 26002 polling stations across the country. In addition, the taskforce, led by the police, provided security during the biometric voter registration exercise and political party campaigns and meetings.

While stringent security measures were put in place to ensure that party campaigning and meetings were peaceful, this was not the case with respect to the BVR exercise. Unlike on election day, when security official were deployed to the various polling stations, the security services were conspicuously absent from polling centres during the BVR exercise. It appeared that the police had no security plan to safeguard the process other than performing their routine duty of maintaining public law and order.

Given the intense debates that characterised the introduction of the BVR, which suggested the possibility of clashes between opposing political parties during the exercise, one would have thought that adequate security measures would have been put in place to prevent any violence, but this was not done. This created a security void which was filled by thugs, popularly known as 'Macho men', and by political party vigilante groups. 
Taking advantage of the technical, operational and logistical difficulties that characterised the BVR process, these groups instituted various forms of violence, including assault, malicious destruction of property, theft of election equipment and attacks on individuals. A typical case was the alleged assault on the NPP parliamentary candidate for Ablekuma South, Ursula Owusu, and on Abu Jinapor, an aide to the NPP flag bearer. The two were attacked by thugs working for the NDC candidate for the Odododiodoo constituency in the Greater Accra region, Nii Lantey Vanderpuye, over a misunderstanding about the registration process (Daily Guide 2012; Ghana Web 2012).

In another instance the BVR exercise was brought to an abrupt end at the Ahenboborano polling centre in the Tafo Pankrono constituency in the Ashanti region when a group of men riding motorbikes belonging to the NDC thronged the polling centre and seized the equipment of the ECG officials (Citifmonline 2012; Mensah 2012). The confrontation that ensued between the NDC group and NPP youth present at the polling centre resulted in the exercise being halted for the whole day.

Worryingly, the police failed to deal swiftly with most of these incidents and their inability to arrest and prosecute perpetrators of election-related violence made the service very unpopular. The unfortunate pronouncement of Kennedy Agyapong, NPP Member of Parliament (MP) for the Assin North Constituency was an example. The MP made a statement to the effect that he would organise NPP supporters to defend themselves because the police had failed in their duty to protect them. He was also reported to have declared 'war', vowed to lynch any 'fake' security operative and to have made ethnocentric comments about Asantes, Ewes, and Gas (Ghanaian Times 2012; Myjoyonline 2012b).

Although the MP's comments were regrettable and irresponsible and should have led to rapid prosecution, the way in which the police handled the case to some extent confirmed the public perception of political interference in their operations. The MP was charged with treason for declaring 'war' - a patently inappropriate charge which suggested to some critics that members of the incumbent government were using the police to frustrate the MP, who was a fierce critic of government.

Consequently, while some political parties accused the police of failing to control the violence associated with the BVR exercise others believed they had compromised their neutrality and professionalism. These claims were not surprising because for the political parties, especially the NPP and the NDC, it is only when the conduct of the police favours them that they praise the service for showing impartiality and a high sense of professionalism.

For example, while the Ashanti region wing of the NDC accused the TafoPankrono District Police Commander, Superintendent Kwesi Ofori, of selective justice because he prevented NDC thugs from disrupting the BVR exercise at 
the Ahenboborano polling centre, the NPP praised him for acting professionally (Citifmonline 2012; Mensah 2012). Although, most of the allegations levelled against the security services cannot be completely disregarded it is also true that they did everything within their power to keep the peace by effectively and efficiently discharging their duties as stipulated in the Constitution.

To be precise, despite the shortcomings, security was beefed up in various conflict hotspots or flashpoints, enabling the police-military patrol team to work day and night to deter potential troublemakers from fomenting any trouble. The police rapid deployment force was also put on standby to nip in the bud any disturbances by individuals or groups.

The end of the BVR exercise ushered in the campaign season, which was also characterised by intense political tension and pockets of violence and clashes across the country. Three categories of election-related violence identified by Omotola (2010), namely, psychological, structural and physical violence, confronted the police during this period. The psychological violence, which involved political intimidation, death threats, hate speech and defamation or insults and physical violence such as assault, disruption of campaign rallies, arbitrary detention, fighting, arson and defacement of political party posters, seemed to be pronounced at this stage.

Some violent acts were recorded in Kyebi in the Eastern Region, Manhyia in the Ashanti regional capital Kumasi and Agbogbloshie in the Greater Accra region. The police response time left much to be desired. They responded late and, in most cases, failed to arrest and prosecute perpetrators. The structural violence included abuse of incumbency and the politicisation of electoral officials and security personnel. The taskforce had a major challenge in dealing with the structural and psychological forms of violence, being constrained by issues such as lack of evidence, while abuse of incumbency fell within the constitutional mandates of certain state institutions.

One of the biggest challenges was dealing with the so-called 'secret tapes' produced by members of both the NDC and the NPP with the aim of disrupting the elections. Two of the tapes that attracted considerable public discussion were those purporting to be the voices of Yaw Boateng Gyan, national organiser of the NDC and Anthony Karbo, NPP national youth organiser. Gyan was alleged to have said that the NDC had planned to draft some of its members into a special force that would be issued with national security identification cards to enable them to move freely and cause trouble in some parts of the country during the elections. Karbo was accused of planning to disrupt the elections using mercenaries from neighbouring countries (Myjoyonline 2012c; Zamana 2012). A lack of evidence and of equipment that would have enabled the police to identify the voices made their task of investigating the veracity of the tapes extremely difficult. 


\section{Voting days, 7 and 8 December}

For the first time since 1992 voting was held over two days to allow those who were unable to vote on the first day because of the breakdown of some of the BVR machines to exercise their right to vote the following day. Throughout the two days of the elections the task force had the responsibility of manning and protecting all polling stations, the country's borders, electoral offices, voters, ballot boxes, electoral officials and collation centres.

To this end, while the contingency force remained on standby, the mobile force undertook massive patrols in the electoral areas, especially the conflictprone areas, to calm tensions and also to prevent the outbreak of any violence (fieldwork 2013). This helped deter potential troublemakers from fomenting trouble that might have marred the elections. However, the lack of adequate communication devices and means of transportation and the inaccessibility of polling stations due to bad roads sometimes hindered the timely response to emergencies (fieldwork 2013).

On the other hand, the static force, which was most active during the period, manned and protected polling stations and all ECG installations. In all, about 41000 security personnel were deployed nationwide to police the 26002 polling stations (Myjoyonline 2012a).

There was adequate security at polling stations to protect voters, electoral material and officers as well as the ballot boxes. Security officers also ensured that the queue of voters was orderly, stood at the end of queues at $5 \mathrm{pm}$ to ensure that no person joined them after the closing time and also carried out the lawful instructions of the presiding or returning officer of the Electoral Commission (fieldwork 2013). Two to three security officers were stationed at flashpoints to avert any unforeseen threat.

The absence of the police and military in some areas, however, actually created the impetus for some unscrupulous people to engage in violent acts. For example, in polling stations that were manned by the other security agencies such as immigration, fire service and prison service, their presence did not deter would-be perpetrators of violence because, according to some voters, unlike the police these agencies lack powers of arrest and are also not armed (fieldwork 2013). Some polling stations were not manned by any security officers at all (CODEO 2012). Furthermore, in some areas and in spite of the presence of security officers party thugs harassed and intimidated electoral officers for starting the voting process late.

The preliminary statement of the Coalition of Domestic Election Observers (CODEO 2012) recorded 17 cases of harassment or intimidation across the country. The Ashanti region recorded the highest number - six incidents, followed by 
Greater Accra, Central and Northern region, each recording two incidents. The rest of the regions recorded one incident each, except the Upper East region, in which there were no cases of harassment (CODEO 2012). In other polling stations the voting process was disrupted by fighting among voters in the queue according to the CODEO statement.

These incidents notwithstanding, the taskforce did a very good job of ensuring adequate security throughout the two days of the elections and should therefore be commended for their efforts. For instance, despite the insufficient logistical and monetary allowances, some officers who had no communication devices used their own mobile phones to make calls and report cases, without being reimbursed. Others had to travel for two to three days before and after the elections to and from very remote areas just to ensure that the process was carried out smoothly and peacefully.

Security officers also ensured the safe counting of results at the collation centres and, in situations where there was no light, the counting was done by torchlight. Others worked day and night throughout the period, sometimes going without food for the whole day, just to ensure that peace was preserved (fieldwork 2013).

\section{Post-election period}

In the post-election period, which usually lasts until the inauguration of the president, the mobile forces undertook massive patrols in the electoral areas. They monitored post-election activities, intensified patrols throughout the country, especially in potential trouble spots where violence was likely to erupt, and supplied heavy security protection for electoral offices, especially the Electoral Commission headquarters, before and after the declaration of results.

Some officers also maintained security at the borders and ensured the safety of lives and property. In an incident prior to the ECG 's declaration of the final results the police and military cordoned off a building in Dzorwulu in the Ayawaso-West Wuogon in Accra, which was besieged by hundreds of supporters of the NPP, who claimed the commission was able to 'doctor' election results. Journalists from various TV and radio stations were also reported to have been attacked by NPP supporters and thugs after the declaration of the results (Daily Graphic 2012). In this particular instance, the police and military reacted promptly, securing the area against any possible violence by the irate youth of the NPP.

Apart from this, the taskforce continued to protect and maintain the peace of the country throughout the early post-electoral period, especially during the victory rallies of the NDC and the subsequent rally of the NPP at the Kwame Nkrumah Circle's Obra Spot in Accra. Significantly, although the taskforce was 
disbanded, the police and military provided heavy security at the Supreme Court during the adjudication of the NPP's election petition (Ghana News Agency 2013; GBC 2013).

\section{EMERGING ISSUES REQUIRING URGENT POLICY REFORMS}

One issue that became a source of intense public debate, especially between the ECG and the taskforce, in the build-up to the 7 December poll, was the question of who should lead the security of the elections: whether it should be the ECG or the taskforce? The thrust of the matter is that in accordance with section 5 of Ghana's 1996 Security and Intelligence Agencies Act (Act 526), regional security councils (REGSECs) and district security councils (DISECs) must be established in each of the ten administrative regions of the country.

These councils implement government security policies at regional and district levels and provide an early warning to the government of the existence or likelihood of any security threat to the region, to the country or to the government (Security and Intelligence Agencies Act 1996).

The councils are chaired by the regional ministers and the metropolitan, municipal and district chief executives of the respective regions, metropolitan assemblies, municipalities and districts in Ghana, who are all political appointees of the president (Constitution of Ghana 1992). They superintend security issues, meaning that all the state security agencies are under their authority, though they do not take direct instructions from them. However, since the 2000 elections most of the regional ministers and metropolitan, municipal and district chief executives, who sometimes also stand for election, have used their positions as heads of the security council in their respective jurisdictions to interfere in the operations or activities of the NESTF.

Some police officers interviewed, for example, noted that there were occasions when party thugs and electoral offenders who had been arrested were released for no apparent reason in response to directives from some of these government officials (fieldwork 2013). From time to time security officials have been threatened by politicians with transfers to remote areas or with being relieved of their positions.

A classic example during the 2012 elections was a case involving the Commander of the Motor Traffic and Transport Unit (MTTU), ACP Angwubutuge Awuni and the NDC MP for Osu Klottey and former Greater-Accra Regional Minister, Nii Armah Ashietey. Awuni was accused by the former minister of ordering policemen to assault him at a biometric registration centre and also of insulting him. Although the MTTU boss admitted using inappropriate language after he was provoked by threats of dismissal made by the former minister, 
he insisted that the ex-minister had committed an offence by disrupting the registration process.

Subsequently, the Greater-Accra branch of the NDC called for the removal of the MTTU commander or his transfer for acting unprofessionally, but the inspector-general of police ignored the request. The case was later covertly settled by the police administration. But the fact is that the work of the police and other security services is constantly interfered with by politicians who think they are above the law, especially when their party is in power.

This situation has dented the image of the police over the years as they have been accused of unprofessional conduct and of allowing themselves to be used as 'puppets' by incumbent governments to pursue their 'evil' agendas, allegations the police administration has persistently denied. In effect, however, this has led to mistrust of the police and has resulted in politicians and voters resorting to illegal means to protect themselves and their votes, which, in many cases, has led to violent clashes.

For these reasons what the National Security Secretariat, which has oversight responsibility over the operations of the taskforce, sought unsuccessfully to do in the 2012 elections was to have the Electoral Commission provide strategic guidance for the operations of the taskforce, while the NESTF undertook the operational level tasks (Gbevlo-Lartey 2012). That is, instead of the arrangement whereby the IGP and the police commanders at both regional and district levels led the activities of the taskforce, what the National Security Secretariat proposed was that ECG officials take the lead at national and district levels.

In this way the taskforce would be chaired by the heads of the ECG at their respective levels and the heads of the security agencies would only be members of the taskforce. In essence, according to the National Security Coordinator, Lt Col (rtd) Larry Gbevlo-Lartey, 'it is the ECG who would decide the "What" what exactly is the problem in the region or district? What do we need to do?' Once that was decided at that level the taskforce, which is an operational wing of the Electoral Commission, that is, it does not make decisions for the ECG, would implement what the ECG believed needede to be done to help it conduct a successful election.

Once that decision had been made the taskforce would lead the implementation process (Gbevlo-Lartey 2012). This process would ensure that heads of regional, metropolitan, municipal and district security councils, some of whom also stand for election, did not interfere with the operations of the taskforce. However, there appeared to be some kind of apprehension on the part of the ECG, particularly with regard to supervising the military and the police.

This is not a new issue, it was discussed before the 2004 elections, but no major headway was made in resolving the dilemma because it had legal implications. 
Though the taskforce and the ECG failed to agree on the way forward, it is important for the purpose of subsequent elections that this issue is resolved. Finding an amicable solution will go a long way to making the taskforce more independent, boosting the confidence of the public in its operations and preventing political interference in its activities.

\section{CONCLUSION}

The 2012 elections were among the most keenly contested since the 1992 transitional elections. There was also a greater attempt than ever before to keep the elections peaceful. Despite this, all three phases were characterised by violence, posing a serious challenge to the security forces.

One of the largest of these security challenges during the voter registration phase was the introduction of the BVR, which was characterised by the malfunction of biometric machines, creating frustration, tension and violence in a number of constituencies in the country. With hindsight it seems that, while there were growing fears about its successful implementation on election day, the problems during the registration period should also have served as an opportunity for the ECG to marshall the necessary resources and back-up BVR machines.

The NESTF was aware that it would have to be extra alert to avert violent incidents and possible outbreaks of conflict and, in pursuance of this goal, NESTF personnel were deployed to the 26002 constituencies, primarily to maintain law and order but also to ensure that votes were cast in a free, fair and transparent manner, devoid of intimidation. The fact that for the first time there were two days of voting challenged the NESTF beyond its limits, sometimes resulting in delays in its response to emergencies.

During the post-election period, which is usually critical for a country's stability, the mobile force undertook massive patrols in the electoral areas and intensified their patrols throughout the country, especially in potential trouble spots, and ensured heavy security protection of electoral offices, especially the Electoral Commission headquarters, before and after the declaration of results.

In spite of these efforts there was a host of alleged irregularities and electionrelated violence. However, potential outbreaks of conflict were averted by the efficient and collaborative role of the security forces.

Although there is still a perception that the security forces, mainly the police, are often tied to the government in power, we argue that the wider election security task force played a significant and collaborative role in ensuring peaceful and successful elections. But to reduce the burden on the NESTF in future elections and to prevent possible violence, it is necessary to recruit and train more security personnel. 
More importantly, the supporting security services that form part of the NESTF, such as immigration and CEPS, need to be given essential knowledge of the electoral laws in order to have a clearer understanding of what their specific roles or duties are. The effective operation of the NESTF will also be dependent upon the acquisition of the necessary equipment, funding and accommodation. Above all, there is a need for the NESTF, and especially the police, to act professionally and without political interference. This is an essential element in inspiring trust and confidence in the public so as to embolden the security forces to work effectively and maintain peace and stability.

\section{- REFERENCES -}

African Elections. 2012. 'Secret tape Wahala: BoatengGyan admits voice is his but ...' Available at: www.africanelections.org/ghana/news

Alhassan, I. 2012. 'Macho man campaigns against election violence'. Available at: ghanaian-chronicle.com

Aning, K \& E Lartey. 2009. 'Evaluating Electoral Process and the State of Democracy in Ghana'. In The State of Democracy in West Africa. Dakar: Goree Institute.

Ayee, J R A. 1998. 'The 1996 General Elections: An Overview'. In J R A Ayee (ed).

The 1996 General Elections and Democratic Consolidations in Ghana. Accra:

Gold Type Ltd.

Aubyn, AK. 2002. 'Behind the Transparent Ballot Box: The Significance of the 1990s

Elections in Ghana'. In M Cohen \& L Laakso (eds). Multi-party Elections in Africa. UK: Palgrave Macmillan.

Aubyn, F K. 2012. 'Election Observation and Democratic Consolidation in Africa: The Ghanaian Experience'. In K Aning \& K Danso (eds). Managing ElectionRelated Violence for Democratic Stability in Ghana. Friedrich Ebert Stiftung.

Aubyn, F K \& E Lartey. 2012. 'Assessing the Electoral Security Architecture of Ghana'. KAIPTC Monograph (unpublished).

Boafo-Arthur, K. 2008. Democracy and Stability in Africa: The Ghanaian Experience. Claude Ake Memorial paper (CAMP) series No 4. Uppsala: Nordic Africa Institute.

CDD. 2012. 'CDD-Ghana Statement on Creation of New Constituencies'. Newsletter. CODEO. 2012. ' Provisional Report on the Biometric Voter Registration Exercise'. Available at: www.codeoghana.org

Citifmonline. 2012. 'Ashanti NDC accuses Kwesi Ofori of Selective Justice'. Available at: www.citifmonline.com

Coffie, F. 2012. 'Controversy on Creation of 45 New Constituencies'. Available at: gbcghana.com. 
Constitution of Ghana. 1992. Chapter 20 on Decentralization and Local Government. Accra: Parliament of Ghana.

Daily Graphic. 2012. 'GJA asks NPP to apologise for attacks on journalists', December 13.

Daily Guide. 2012. 'President Mills calls for end to biometric registration violence'. www.dailyguideghana.com

Danso, K \& E Lartey. 2012. 'Democracy on a Knife's Edge: Ghana's Democratization Processes, Institutional Malaise and the Challenge of Electoral of Violence'. In K Aning \& K Danso (eds). Managing Election-Related Violence for Democratic Stability in Ghana. Friedrich Ebert Stiftung.

Danso, S \& F Adu-Afful. 2012. 'Fruitcake, "Madmen", “all-die-die"'. In K Aning \& K Danso (eds). Managing Election-Related Violence for Democratic Stability in Ghana. Friedrich Ebert Stiftung.

Diamond, L. 1999. 'Introduction'. In L Diamond \& MF Plattner (eds). Democratization in Africa. Baltimore/London: The Johns Hopkins University Press.

Frempong, A K D. 2007. 'Constitution-making and Constitutional Rule in Ghana'. In J A R Ayee (ed). Ghana at 50: Government, Politics and Development. Accra: Friedrich Ebert Stiftung,

Frempong, A K D. 2012. Electoral Politics in Ghana's Fourth Republic: In the Context of Post-Cold War Africa. Accra: Yemens Press Limited.

Gbevlo-Lartey, L. 2012. 'Security Arrangement for the 2012 Elections: Assurance Statement by the National Security Coordinator'. Paper presented at the KAIPTC Colloquium on 'Preserving National Security in Elections 2012 and Beyond', Accra, Ghana, 23 October.

Ghana Broadcasting Corporation. 2013. 'Police ready to avert chaos around premises of Supreme Court'. Available at: gbcghana.com/index.php?id=1.1232230

Ghana Constitution. 1992. Chapter 15 on the 'Police Service'. Accra: Parliament of Ghana.

Ghana News Agency. 2012. 'Security Personnel on Election Monitoring to Carry Duty Reminder Notes'. Available at: www.ghana.gov.gh

Ghana News Agency. 2013. 'Heavy Security Presence at Supreme Court Premises'. Available at: http: / / www.ghana.gov.gh/

Ghana Web. 2012. 'Mills condemns violence in Odododiodio, et al'. Available at: www.ghanaweb.com

Ghanaweb. 2012. 'Secret Tape! NPP plans to disrupt elections with mercenaries?' Available at: www.ghanaweb.com/GhanaHomePage/health

Ghana Police Service. 1970. Section One (1) of the Ghana Police Service Act (Act 350). Accra: GPS.

Ghana Police Service. 2008. 'Document Establishing the National Election Security Task Force'. Accra: GPS

Ghanaian Times. 2012. 'Kennedy Agyapong Placed Under Arrest'. Available at: newtimes.com.gh 
Government of Ghana. 2012. 'National Elections Security Task Force Briefs Minister'. Available at: www.ghana.gov.gh

GraphicOnline. 2012.' Security Task Force deploys 41,000 personnel to police poll'. Available at: graphic.com.gh

Gyimah-Boadi, E. 1999. 'Ghana's Elections: The Challenges Ahead'. In L Diamond \& M F Plattner (eds). Democratization in Africa. Baltimore/London: The Johns Hopkins University Press.

Gyimah-Boadi, E. 2003. 'Ghana: The Political Economy of "Successful" Ethnoregional Conflict Management'. In S Bastain \& R Lukham (eds). Can Democracy be Designed?: The Politics of Institutional Choice in Conflict-torn Societies. London/New York: Zed Books.

Hounkpe, M \& A B Gueye. 2010. The Role of Security Forces in the Electoral Process: The Case of Six West African Countries. Lagos: Friedrich Ebert Stiftung.

Jeffries, R \& C Thomas. 1993. 'The Ghanaian Elections of 1992'. African Affairs 92(368).

KAIPTC. 2012. 'Preserving National Security in Elections 2012 and Beyond'. Paper presented to the KAIPTC Colloquium on 'Ensuring Peaceful Elections in Ghana', Accra, Ghana, 23 October.

Mensah, M. 2012. 'Police Will Remain Professional, Deal with Trouble Makers IGP'. Available at: www.modernghana.com/news/391457/1/police-willremain-professional-deal-with-trouble-.html

Mishio, D K. 2012. 'Ensuring Peaceful Elections in Ghana - Role of the Ghana Armed Forces'. Paper presented at the KAIPTC Colloquium on 'Ensuring Peaceful Elections in Ghana' Accra, Ghana, 23 October.

Myjoyonline. 2012a. 'Security begins deployment ahead of Friday's historic elections'. Available at: elections.myjoyonline.com / readnews.php?file=157 Myjoyonline. 2012b. 'Chaos at Police HQ over Kennedy Agyapong arrest'. Available at: politics.myjoyonline.com/pages/news/201204/85053.php

Myjoyonline. 2012c. 'Secret tape Wahala: BoatengGyan admits voice is his but ...' Available at: politics.myjoyonline.com/pages/news/201209/93380.php

Omotola, S. 2010. 'Explaining Electoral Violence in Africa's New Democracies'. African Journal of Conflict Resolution 10(3).

Oquaye, M. 1995. 'Human Rights and the Transition to Democracy under the PNDC in Ghana'. Human Rights Quarterly 17(17), August.

Peace FMOnline. 2012. ' NDCSecret Tape Out'. Available at: elections.peacefmonline. com/politics/201209/133525.php

WANEP. 2012. 'Statement: Peace and Security Update - Ghana 2012 Election'. Available at: politics.myjoyonline.com/pages/news/201211/98080.php

Zamana, D. 2012. 'NPP's Secret Tape Out - plans to disrupt elections with mercenaries - NDC'. Available at: www.modernghana.com 